\title{
The Figurative Significance of Intimate Possession in Affinity
}

\author{
Ya-Ju Yeh \\ Department of English, Aletheia University, Taiwan \\ Received December 12, 2019; Revised February 16, 2020; Accepted February 24, 2020
}

Copyright $(2020$ by authors, all rights reserved. Authors agree that this article remains permanently open access under the terms of the Creative Commons Attribution License 4.0 International License

\begin{abstract}
Affinity (1999), the British writer Sarah Waters' second novel, unfolds a suspenseful romance between two heroines, Margaret Prior and Selina Dawes in the setting of Millbank Gaol, one of London's most notorious prisons in the $1870 \mathrm{~s}$. Margaret Prior, an upper-class spinster, becomes a lady visitor of the prison, eager to escape her troubles and be a guiding figure in the lives of the female prisoners. Margaret finds herself increasingly fascinated by an apparently innocent inmate, the enigmatic spiritualist Selina Dawes. Selina takes a material strategy in order to gain Margaret's trust, which is, delivering Margaret something as gifts in the way of 'spirits'. Those objects are nothing more than ordinary ones regarding Selina, for instance, her own rope of hair or her neck collar. The personal possession, which serves as the very metonymy of Selina's affection or even herself, converts Margaret to believe in Selina's real spirit practice. Objects of possession assuredly function as a means of expressing the self or the way one lives and experiences so that they exert profound effects on manoeuvring the affinity relation. This paper aims to delve into distinct revelations of objects possessed and interpreted by the protagonists, examining how possession becomes an embedded expression of class politics in the prison and how objects involve mistress and maid relations resulting in diverse consequences of intimacy.
\end{abstract}

Keywords Intimacy, Possession, Sarah Waters, Affinity

\section{Introduction}

Affinity (1999), Sarah Waters' second novel, unfolds a suspenseful romance between two heroines, Margaret Prior and Selina Dawes in the setting of Millbank Gaol, one of London's most notorious prisons in the $1870 \mathrm{~s}$. Margaret Prior, an upper-class spinster, recovering from her father's death and her subsequent suicide attempt, has struggled with her lack of power while living at home with her over-involved mother, despite Margaret being almost thirty years old. She becomes a lady visitor of the prison, eager to escape her troubles and be a guiding figure in the lives of the female prisoners. Margaret finds herself increasingly fascinated by an apparently innocent inmate, the enigmatic spiritualist Selina Dawes among Millbank's murderers and common thieves. Sympathetic to the plight of this innocent-seeming girl, Margaret offers guidance and experiences a growing friendship during her visits. The friendship develops later into unseemly passion, which drives Margaret curiously to a spooky deceit in being complicit in Selina's escape. In addition to its engagement of Victorian spiritualist practices, the novel sheds lights on the Victorian class problem with a love triangle of Margaret, Selina and Ruth Vigers, originally Selina's maid and pretending to be Margaret's maid for the contrivance. Using settings in both the prison and the household, Waters parallels the seemingly rigid panopticon prison mechanism of criminals and solid social class relations of servants, simultaneously revealing the twists and turns derived from the voices of characters of distinctive positions.

In Affinity, Waters incorporates various critical debates concerning spiritualism, prison power structure, and confinement on women's roles in the Victorian era. Those debates also give complicated scopes to female and perhaps homosexual experience in the novel. Among those debates, Waters' focus on the critical panoptic gaze primarily resonates with Michel Foucault's 1975 work, Discipline and Punish: The Birth of the Prison, and his discussion of Jeremy Bentham's panoptic structure of design [1]. Boehm argues that Millbank prison serves as a metaphor for the prison-house of historiography; the prison itself is not simply a structure of bricks and mortar, but rather the disciplined bodies of these women [2]. Also emphasizing the theme of prisons, Armitt and Gamble have investigated how Waters moves from Foucault's explanation of the panopticon's mechanism to reveal it as 
an "optical illusion" [3, p.142]. Moreover, Kym Brindle contends that letters supplement diaries as a significant, if covert, presence in the novel and instead extensionally employs letters as a ghostly panoptic means of an invisible gaze, claiming that "the two diarists are effectively controlled by one over-seeing reader/writer who requires both diaries and letters to orchestrate intersecting texts" $[4$, p.78]. The above criticism emphasizes how criminality and its historical, spatial ideologies of social justice are explicitly manifested and intermingled in the novel.

If haunting and spectrality in the novel, as Barbara Klonowska analyzes, appear both as manifestations of suppressed emotions and a trace of powerful social conflicts, class is one of the most compelling issues in the novel [5, p.173]. Waters actually shapes the intimacy between the two protagonists permeated with class terms as well as trapped in the world of séances and shadows profoundly premised on a system of material media. As Margaret continues her frequent visits with those woman criminals, Selina slowly convinces Margaret of how her power over spirits may be exercised mentally. As an assistant in her father's scholarly rational organization of book collection, Margaret is uneasy about accepting what Selina tells her about spiritualism. Selina takes a material strategy in order to gain Margaret's trust, which is, delivering Margaret something as gifts in the way of 'spirits'. Those objects are nothing more than ordinary ones regarding Selina, for instance, her own rope of hair or her neck collar. Their materiality reveals Selina's physical presence in the gaol; nevertheless, her 'spirit' sends them to Margaret's room in Chelsea. The personal possession, which serves as the very metonymy of Selina's affection or even herself, converts Margaret to believe in Selina's real spirit practice. These objects of possession thereafter propel Margaret to support Selina's plotted prison escape. Selina's ultimate success in her spiritual fraud is made possible not only by Ruth Vigers' secret assistance, but also by these material media. In short, these material media demonstrate the palpable evidence of crime and the potential tension resulting between the upper-class lady and the prisoner.

Objects of possession assuredly function as a means of expressing the self or the way one lives and experiences so that they exert profound effects on manoeuvring the affinity relation. Bill Brown explores possession as the happiest relationship in which the only intimacy one really enjoys is that of particular significance. There is indeed a persuasive account of how human beings achieve an intimate relation with their possessions. Possession also weaves and interweaves one's temporal strands of life since one's habitual interactions with objects may both bring them to life and impose order on their life [6]. Such habits of possession further mark time and allow one to escape from time, as "performing the present in concert with the future and the past" [6, p.64]. Brown's concept of possession may portray Selina's brilliant use of material media in the relation between her and Margaret. This paper delves into distinct revelations of objects possessed and interpreted by the protagonists: the first section articulates how possession becomes an embedded expression of class politics in the prison; the second section examines how objects ultimately stem from class implications and involve mistress and maid relations, resulting in diverse consequences of intimacy or indifference.

\section{The Lady and the Inmate}

At the outset, Margaret undertakes to perform duties as a Lady Visitor to the Millbank Gaol under the suggestion of Mr Shillitoe, an old friend of her father's. The Lady Visitor was a conventional system since the dispensing of charity was an integral part of many Victorian ladies' lives [7, p.59]. Mr Shillitoe informs her of certain possible influences from such duties: "a lady... has left her comfortable life, solely to visit them, to take an interest in their mean histories. Let them see the miserable contrast between her speech, her manners, and their own poor ways, and they will grow meek, they will grow softened and subdued" [8, p.12]. The function of the Lady Visitor is regarded as an extension of the traditional female nurturing role. Prison visits give those respectable ladies chances "of exercising power over the lives of others through the decisions they took to provide assistance to the old, the sick and the needy" [7, p.59]. In fact, such visits offer them a means of escape from the limitations of their everyday domestic experience and enable them "to demonstrate their organisational abilities, to show their own personality, and to gain satisfaction from their achievements" [7, p.59]. It is thus believed that the Lady Visitor will certainly purify the criminal's psyche while being the intimate or counsellor for criminals to make their future life a better one. For the ladies, it is a positively effective matter "of influence, of sympathies, of susceptibilities tamed" with the prisoners [8, p.47].

The meaning and effect of the Lady Visitor could be totally dissimilar to those of the prisoners. Under the crimes of fraud and assault, Selina has been imprisoned for eleven months when Margaret begins visiting Millbank. Selina penetrates Margaret's mental illness with intentions to "look on women more wretched than yourself, in the hope that it will make you well again" [8, p.47]. To grasp Margaret's attention, the very first object Selina plots to deliver is the flower, which insinuates into Margaret's first encounter with Selina. In the dark, colorless cell, Selina unlike other inmates, impresses Margaret with her quiet manners and "had a flower there, between her fingers - a violet, with a drooping stem" [8, p.27]. The violet color does not match up with the prison atmosphere, instead rendering Selina a sacred disposition of spirit in great contrast with the black dirty cell: "she put the flower to her lips, and breathed upon it, and the purple of the petals gave a quiver and seemed to glow" [8, p.27]. 
The violet flower is also a colourful living thing contrary to the gloomy image of prison. Precisely, the flower is the most unlikely prison-related object since the message is harshly censored and personal belongings are absolutely not allowed. Then, as Margaret returns from the ward, she beholds orange-blossoms in a vase from the mantel placed upon her desk: "the orange-blossoms I have before me now so heavy upon the close air of my room, it makes me giddy" [8, p.224]. She rings the servant bell to confirm where the blossoms come from and nobody is able to offer answers. Confused and frightened with such a flower gift, Margaret soon associates the gift with Selina, with whom she becomes more and more obsessed despite the ward watcher Miss Haxby warning her of dangerous sympathy with the wretched situation and limited freedom of the prisoners. The flower is an incontestable material evidence of Selina's presence in the gaol.

The second object from Selina is her own hair. Margaret coincidentally visits the "Own-Clothes Room" in the ward, where the women's dresses and hats and shoes are kept when they begin their Millbank life. Each prisoner has her own box. She begins to wonder about the contents of Selina's box and see what it holds. She witnesses and touches Selina's belongings: "Her hair. Her hair, bound tight and plaited into one thick rope, and fastened, where it had been cut from herm with coarse prison twine" [8, p.239]. In a spiritual enchantment, Margaret has a desire to keep and take good care of it. Margaret fails to steal the hair from the Own-Clothes Room under the matron's strict supervision. However, in a couple of days, she finds something in her room: "It was a curling rope of yellow hair, as thick as my two fists. It was the hair that I had tried to steal from Millbank Prison-it was Selina's hair. She had sent it to me, from her dark place, across the city, across the night. I put my face to it" [8, p.258]. She ascertains that it is the same object because of its "smelt of sulphur" like the one she smelled and touched with her own fingers in the Room [8, p.258]. Margaret once again confirms the validity of Selina's claim on the mighty power of the 'spirit'. Selina's rope of hair furthermore connected to her past, the time she still had freedom and a normal life, reminding Margaret how Selina may suffer from horror and nightmares in the gaol.

Right after Margaret carefully prepares money for their freedom abroad, the foremost object Selina calculates is needed to accomplish the last step of her escape is her neck collar. Though greatly inspired by Selina's proposal of freedom, Margaret is hesitant to carry out the plan since she could abandon her life forever: "Leave Mother. Leave Helen and Stephen, and Georgy, and the children still to come. Leave my father's grave. Leave my ticket to the reading-room at the British Museum" [8, p.273]. Again in the night, Margaret discovers something wrong with her own diary, "the book seemed to bulge a little; and when I tilted it, something slithered from it-something slim and black, it fell upon my skirt and then was still. When I touched it, it seemed warm" [8, p.294]. Sensitive to Selina's usual 'spiritual' gifts, Margaret knows what the object is at once outside of her instincts: "a velvet collar, with a lock of brass. It was the collar Selina used to wear, and she had sent it to me" [8, p.294]. Margaret is in ecstasy at the approaching free future life with Selina's company and love: "it was my reward, I think, for all my cleverness with Stephen!" [8, p.294] Margaret immediately puts on the collar as if their souls are united and they are each other's affinity partner: "I stood at the glass and fastened it about my throat. It fits, but tightly: I feel it grip, as my heart pulses, as if she holds the thread to which it is fastened and sometimes pulls it, to remind me she is near" [8, p.294]. The collar intensifies a possible future vision of Selina despite her present imprisonment, hence implying Margaret's inward thoughts and outward activities under Selina's mighty spiritual control.

These objects, ostensibly from the imprisoned Selina, are recognized as a metonymy of Selina. Selina makes her possession so valuable and acquaints Margaret with her usual delicate, mysterious delivery manners: "They come every day now, the tokens from Selina. They come as flowers, or as scents; sometimes they come only as a find an ornament taken up and set down crooked, the door to find an ornament taken up and set down crooked, the door to my closet ajar and my dresses with marks of fingers on the velvet and the silk ..." [8, p.285]. These objects act as metonymies of Selina; they are closely associated with her attribute of delicacy on the one hand and also refer to her affinity to Margaret on the other. These objects, as if an embodiment of an invisible séance between them, "make the space between us thick. They make a quivering cord of dark matter, it stretches from Millbank to Cheyne Walk, it is the cord through which she will send me herself" $[8$, p.285]. Selina's possession assuredly substitutes for her existence, to which Margaret is spontaneously conditioned.

This metonymic effect of Selina's possession has been generated from Margaret's ambivalent sympathy with Selina's disguised solitude. Selina realizes in advance Margaret's habit of diary or letter writing as an exit for her unaccepted self in upper-class social decorum, and contrives to send Margaret tokens in letters before Margaret begins to perform the duty of the Lady Visitor. Margaret hears from Miss Brewer, who handles the prisoner's mail, that Selina Dawes is the only woman in the gaol for whom she never had a letter within the past twelve months; the women of Millbank are allowed to send and receive one letter every two months [8]. Margaret is so astonished that Selina has no friends or family to remember her despite Miss Brewer's belief that some women in the ward keep their secrets to themselves: "To know that there was no-one made the solitude and silence in which she sat seem to grow thicker . . . Dawes does keep her own secrets; she keeps them even there, at Millbank. And I remembered, too, something another matron told me once ---that, handsome as Dawes was, no 
prisoner ever sought to make a pal of her. I understood that now" [8, p.82]. The absence of communication (letters) trigger Margaret's affection and also leaves her off guard regarding Selina. Margaret imagines how remarkably miserable it would be if no one in the outer world missed Selina, visited her or sent her letters and directly allies herself with Selina and feels a rush of pity for her, "what I thought was: You are like me" [8, p.82].

The strength of such metonymic possession is emphasized in the exemplification of Selina. According to Brown, as humans transform the merely owned into the genuinely possessed, human beings turn these "good objects" into personalities that must be subsequently managed because the quotidian significance or the utter ordinariness of the things depends on the subject retaining control of the material object's vitality. It is natural that one's habitual interactions with objects "bring them to life and impose order on that life" and "mark time and allow [one] to escape from time [6, p.64]. Originally owned by Selina, the flower, the hair, and the collar, in particular the latter two, are unquestionably elevated into an inseparable relationship with their owner as they signify Selina's life timeline: her intricate past, her imprisoned presence and her foreseeable future. If humans and their possessions truly achieve an intimate relation, as Brown contends, Selina's possession is apparently "an object has its moods, caprices, like any living person", from whom Margaret alone can understand $[6, \mathrm{p} .65]$. Selina entirely grasps such attributes of her possession and takes advantages of them to get Margaret hooked. Selina's three objects of possession exert a profound effect upon Margaret: she creates the illusion of sameness and continuity over those objects and against the facts of disorder and change occurring in her reality.

Selina's material strategies of possession play a prominent role in the manipulation of the relation between the Lady Visitor and the imprisoned inmate, as well as the matron and the prisoner. The objects for Margaret are simply one of the puzzles in Selina's plan. Selina also bestows the matron Mrs Jelf with a locket of a shining hair inside (actually stolen from Margaret) to soothe her lost pain for her little boy who died at four years old. Selina therefore already wins the matron's trust and even has Mrs Jelf carry letters outside the prison unknown to the prison post-handler. Selina's strategy overturns the power structure of the prison in two senses: one is the Lady Visitor and the criminal, and the other is the matron and the prisoner. The relationship of the Lady Visitor and the inmate is reversed when Margaret is alligned with Selina's wretched situation, rather than a guiding influence; the position of the matron and the prisoner is the same when Mrs Jelf receives the locket gift and desires to return Selina's kindness, rather than maintain strict supervision [8, p.337]. The sympathetic influence of the Lady Visitor is realized and the rigid supervision of the matron is overcome and disintegrated by Selina's material politics of affinity. She is an expert at spiritual fraud and a master in the manipulation of objects with which one may be engaged. These objects help deconstruct the power structure established as an omniscient gaze of the panoptic prison, thus making both Margaret and Mrs Jelf complicit in Selina's escape plan

\section{The Lady and the Maid}

Selina's material trickery would not have succeeded so thoroughly without Ruth Vigers, who contributes much to a growing affinity between Margaret and Selina. As Vigers comes to the Priors' lady's maid recruit which is also pre-designed by Seina, Margaret has an unfavourable impression of Vigers' long-faced, plain looks. Mrs Prior rashly hires Vigers because plain maids are always "more faithful" and the plain Vigers "would be a good girl" [8, p.69]. The employer's misconception of plain maids emerges by virtue of the maid's handsome beauty often leading to the seduction of a young mister or gentleman visitors. Hence most employers prefer a plain sensible maid who "would know her place all right" [8, p.69]. Vigers then becomes one of the Prior family's maids. In the trivial domestic household of the Priors, there is little description about Vigers for she is merely one among other ordinary maids. Vigers requests nothing but a little room for herself. It is a bit weird yet still acceptable for masters. Unfortunately, Ruth Vigers is a shadow figure who Selina sends to supervise Margaret in the house, plain yet never a faithful maid as expected. Vigers becomes an advocate of Selina; she is able to see, hear, and contemplate in her dark cell all concerning Margaret.

Vigers' first task is to read Margaret's mind by secretly gazing into her diary in advance. Vigers notices Margaret has a habit of writing her diary and considers "that book was like [her] dearest friend" [8, p.111]. Severely repressed by her mother, Margaret writes all her deepest thoughts in her diary to keep them secret. It is the relief for her unbearable domestic pressure. The diary exposes so much private information, including "all [her] secrets-all [her] passion, all [her] love" [8, p.339]. Selina soon realizes the importance of Margaret's diary via Vigers. Selina precisely describes the way Margaret writes: "Even should you write it . . . in the darkness of your own room, with your door made fast, and your lamp turned very low" [8, p.111]. Margaret doubts how Selina perceives the details through the spirit, whereas Selina explains that it is her own habit of previously keeping a diary at night in the darkness. The truth is: it is Vigers who hides to discern Margaret writing at midnight, letting Selina foretell Margaret's thoughts during visits. Observing the deepest desire for affection and intimacy in Margaret's mind, Selina inscribes her own name in Margaret's diary, the name of Selina, instead of Dawes or her full name. She begs Margaret to keep her name on the book for the reason that "They call me Dawes here, like a 
servant. If anyone were to say Selina to me now, I think I should hardly turn my head to answer. Selina- Selina I have forgotten who that girl is! She might be dead" [8, p.112]. Her request is linked to Margaret's obsession with her name specifically for her father or her previous lover, Helen. As Margaret confesses that "women's books could only ever be journals of the heart", Ruth reads Margaret's desire "has crept across these pages, after all. [She] can see the crooked passage of it, it grows firmer as the paper turns. It grows so firm at last, it spells a name-Selina" [8, p.241]. With abundant secrets from the diary provided by Ruth and manipulated by Selina, Margaret has been completely beguiled by Selina's professional spiritual practices.

Vigers' second task is to deliver letters and tokens to Margaret as if delivered by Selina. Step by step, Selina sends the flower, the hair and the collar to Margaret as tokens of intimacy as aforementioned. Yet these objects, pretence tokens of love, aim to bait Margaret into a contrived plan of escape. Mrs Jelf, the matron in charge of Selina's cell, is quite loose about Selina's letters out of sympathy, mainly from Ruth: " "there was nothing harmful in them'-nothing save kind words and, sometimes, flowers" [8, p.337]. Echoing Margaret's impressive encounter with Selina of the flowers, Vigers secretly adorns the orange flowers in Margaret's room, playing ignorant about them when Margaret asks who brought them. Then, Vigers arranges the hair at the pillow as the diary reveals the procedure of Margaret's failed stealing of it from the Own-Clothes Room. Lastly, the collar from Selina appears to a surprised Margaret when she opens her diary in the drawer. These objects, transmitted in extraordinarily delicate feminine ways, leave no suspicious traces so that Margaret is lured into the trap.

Vigers' tasks as well as her affinity with Selina designate the core of the whole project. To trace back, Vigers is the lady's maid in Mrs Brink's house at the outset. Mrs Brink, a wealthy aged lady, offers Selina a luxurious residence in Sydenham with a window view of the Crystal Palace. Like Margaret, Mrs Brink trusts in Selina's strength to evoke spirits. She introduces Selina into the upper class social circle with their strong interest in spiritualism, and also assigns Vigers as Selina's lady's maid. Traditionally the principal duty of the lady's maid is her personal attendance on her mistress: "she ought to possess the qualifications of propriety and polite behaviour; and her conduct should be uniformly influenced by correct principles, and strict regard to religious and moral obligations .... her education, and share of the useful and ornamental branches of female acquirements, ought to be considerable; neatness and gentility of person and address will be great recommendations; and cheerfulness of temper and mildness of manners will ensure her the esteem and respect of her superiors" [9, p.97]. On such basis of the lady's maid's principles, Vigers gently and quietly deals with Selina's personal chores, "not like Betty used to come but like a real lady's maid, like a ghost" [8, p.119]. Also being a maid of proper manners, Vigers always keeps her eyes on the floor, "not looking at [Selina]" $[8$, p.120]. Selina feels natural and comfortable about the way Ruth serves her: "Ruth brought more hot water and took my pot, which was not at all like Betty taking it, and made me blush" $[8, p .120]$. Selina intimately calls her "Ruth", a capable lady's maid who has insights into her mistress's taste and preferences. For Selina, Vigers is Ruth, who is her considerate, inseparable companion.

If Ruth is unquestionably a perfect, capable lady's maid for Selina, Vigers is a servant of plain looks and even without a first name for Margaret. The only attribute might be that her last name is pronounced more smoothly than those of the other maids. When Mrs Jelf seeks Vigers for Selina after the escape, Margaret for the first time hears the connection between Selina and Vigers, hysterically repeating the words: "Vigers, my servant, Selina's maid" [8]. Margaret opines that Vigers is such an insignificant servant that it is impossible for her to be Selina's maid. Margaret hardly remembers what Vigers is really like: "I could not even recall the details of her face, her look, her manners. I could not say, cannot say now, what shade her hair is, what colour her eye, how her lip curves-I know she is plain, plainer even than I" $[8$, p.340]. Maids are coarse beings for Margaret. During many sleepless nights, Margaret always hears the maids on the attic stairs: unlacing boots, slamming bolts, and so on. There is no exception in the fact that Vigers is a maid invisible and weightless to Margaret. As a matter of fact, Vigers is likely faceless and voiceless, and could have been thoughtless and mindless in Margaret's imagination. Margaret and Mrs Jelf enter Vigers' little room for clues, yet the room is cold and quite empty: "the emptiest room, it seemed to me at first, that it was possible to imagine: a room that held nothing, like the cells at Millbank, a room that had made nothing a substance, a texture, or a scent. Its walls were colourless, its floor quite naked but for a single strip of rug, worn to the weave. It had a shelf, with a bowl, and a jug that was tarnished, and a bed, with yellowing sheets, that were twisted and bunched" $[8$, p.341]. The emptiness of the room is normal for maids. For Vigers, it is much more than normal since she is very cautious with everything concerning herself. As if she never exists in this little room, Vigers is the invisible lady's maid in the Prior household, and also the traceless spirit between the household and the prison.

If Selina's objects of possession, the rope of hair and the neck collar for instance, carried and delivered by Vigers, constitute an affinity relation between the lady visitor and the imprisoned inmate, they are not only metonymies to Margaret but also to Ruth. There are apparently two layers of significance in these metonymic objects. The first layer of the objects refers to their similar meanings to Vigers as to Margaret because Vigers 
cordially admires Selina. Among the letters passed between Selina and Vigers under the cover of Mrs Jelf, these tokens of love for Margaret are eventually those of love for Vigers. Her affinity with Selina must be concealed and endured temporarily for an upcoming plan. For Vigers, more significantly, they could be metonymies that forwardly substitute future freedom and fortune with Selina. These objects are a more complicated form of meta-metonymies as Selina sends tokens to Margaret via Vigers. After the plan is terminated, Margaret finds that Ruth has taken everything except her diaries. Vigers cleans and presses and folds as usual, and "kept neat, kept ready" when she takes items from Margaret's dressing-room- - "gowns and coats, and hats and boots and gloves and brooches-things. . . to make a lady of her, things that she has handled in her time here. . . and, of course, the clothes I bought Selina" [8, p.340]. Vigers would absolutely never give up Selina's possessions due to their metonymic importance, whereas she extremely disregards Margaret's diaries.

As a maid, Vigers overturns the domestic hierarchy of mistress and maid with her successful disguise in the Priors. As the sturdy system of servants in the household aims to ensure their dedication and loyalty as their masters expect, the plainest maid or the most inconspicuous servant could have been malevolent to their masters. Servants are required to live a voiceless and soundless existence in the household, obeying the system established for the masters' own advantages and benefits. Such silence may imaginably transform into silent threat. Vigers' plain looks and indistinguishable manner propel Margaret to disregard her existence and show no concerns for her. However, Margaret reflects on her company with Selina during these months and belatedly realizes what happened to her: "Every time I stood in Selina's cell, feeling my flesh yearn towards hers, there might as well have been Vigers at the gate, looking on, stealing Selina's gaze from me to her ... All the time I lay in my bed, turning, turning with the drug on me, feeling Selina come, it was Vigers that came, it was her shadow on my eye, her heart that beat to match Selina's-while mine struck out some weak, irregular rhythm of its own" [8, p.341-2].

When it comes to the end, Margaret considers Vigers as the one who contrived to deceive both Selina and her: "I have been robbed, I thought, by my own servant! I'll have them both at Millbank! I'll have them put in separate cells, and make Selina my own again!" [8, p.342] The position of the master and the servant could have been reversed because it is Vigers who instigated such an elopement. In parallel with the power system of the prison, the power structure of the household is destabilized by such an ordinary maid who even organizes a robbery plan from her mistress although Vigers is, in effect, not ordinary at all.

\section{Conclusions}

Selina's material strategies of possession overturn the power structure of the prison in two senses: one is the Lady Visitor and criminals, and the other is the matron and the prisoner, whereas Vigers does the same with the domestic hierarchy of mistress and maid with her successful disguise and physical manoeuvrability. Their trickery invokes the fragmentary, incomplete, and contradictory accounts embedded in the Victorian conventional power structure of female confinement. Selina deceives those who are indulgent regarding their past miserable memories or those who are unable to improve their psychological weakness. At the end of the novel, it is revealed that Vigers plays an aggressive part in her connection and seduction with Selina in the whole project of fraud. The affinity between the lady and the inmate, the matron and the inmate, as well as the lady and the maid in the class structure could have been more profound than the difference between all of them. Affinity discloses how a material manipulation has taken place in class politics concerning both the space of the prison and the household, which proves their underlying possibilities of impotence and fragility once again.

\section{REFERENCES}

[1] Foucault, Michael. Discipline and Punish: The Birth of the Prison. Trans. Alan Sheridan. New York: Vintage Books, 1995.

[2] Boehm, Katherina. "Historiography and the Material Imagination in the Novels of Sarah Waters." Studies in the Novel 43.2 (2011): 237-57.

[3] Armitt, Lucie \& Sarah Gamble. "The Haunted Geometries of Sarah Waters's Affinity.” Textual Practice 20.1 (2006): 141-59.

[4] Brindle, Kym. "Spectral Diarists: Sarah Waters's Affinity and Melissa Pritchard's Selene of the Spirits." Epistolary Encounters in Neo-victorian Fiction: Diaries and Letters. New York: Palgrave Macmillan, 2013. 64-90.

[5] Klonowska, Barbara. "Haunting across the Class Divide: Sarah Waters's Affinity and The Little Stranger." Avant 8.2 (2017): 171-8.

[6] Brown, Bill. A Sense of Things: The Object Matter of American Literature. Chicago: The University of Chicago Press, 2003.

[7] Horn, Pamela. Life as a Victorian Lady. Stroud: Sutton, 2007.

[8] Waters, Sarah. Affinity. New York: Riverhead Books, 1999.

[9] Kobayashi, Akio ed. British Servants: A Collection of Early Guides and Companions. Vol. 5. Osaka: Eureka, 2006. 